\title{
Morphogenesis and Molecular Characterization of a Little Known Soil Ciliate, Oxytricha nauplia Berger et Foissner, 1987 (Ciliophora, Sporadotrichida)
}

\author{
Yang BAI ${ }^{1}$, Song LI' ${ }^{1}$, Yuan $\mathrm{LI}^{1}$, Miao MIAO ${ }^{2}$, Xiaozhong $\mathrm{HU}^{1}$ \\ ${ }^{1}$ Institute of Evolution and Marine Biodiversity \& Key Laboratory of Mariculture, Ministry of Education, Ocean University of \\ China, Qingdao 266003, China; ${ }^{2}$ College of Life Sciences, University of Chinese Academy of Sciences, Beijing 100049, China
}

\begin{abstract}
A Chinese population of Oxytricha nauplia Berger et Foissner, 1987 was recently discovered from the surface soil in the Kuisu Valley, Huhhot, China. Its morphology corresponds well with that of the original population in the body size and shape, the absence of cortical granules, two macronuclear nodules and two micronuclei. Both morphogenesis during binary fission and small subunit of ribosomal gene (SSU rDNA) of the species were first investigated. Though earlier dividers are unavailable for this species, morphogenesis almost proceeds as in congeners by given stages. The SSU rDNA sequence of $O$. nauplia is 1728 bp long and has a DNA G+C content of $45.72 \%$. Phylogenetic analyses revealed that Oxytricha nauplia grouped with $O$. paragranulifera first with high support, and then clustered into a subclade including Onychodromopsis flexilis, Paroxytricha ottowi, Paroxytricha longigranulosa and Rigidothrix goiseri, which branched off most congeners, but clustered into the Oxytrichidae clade.
\end{abstract}

Key words: ciliature; ontogeny; oxytrichid; phylogeny; SSU rDNA

\section{INTRODUCTION}

Ciliates in subclass Hypotrichia Stein, 1859 have been a consistent focus of researches on taxonomy and systematics (e.g. Müller 1773; Stein 1859; Kahl 1932; Bick 1972; Borror 1972; Corliss 1979; Berger and Foissner 1997; Song and Wilbert 1997a; Berger 1999; Foissner 1999; Song and Warren 1999; Song 2001; Foissner 2012; Foissner et al. 2008; Chen et al. 2013; Jiang et al.

Address for correspondence: Xiaozhong Hu, Institute of Evolution and Marine Biodiversity \& Key Laboratory of Mariculture, Ministry of Education, Ocean University of China, Qingdao 266003, China. Tel.: +86 532 82031610; E-mail: xiaozhonghu@ouc.edu.cn
2013; Shao et al. 2013a, b, 2014; Dong et al. 2016; Fan et al. 2016; Kumar and Foissner 2016; Kumar et al. 2016; Luo et al. 2016; Pan et al. 2016; Chen et al. 2017a, b; Gao et al. 2017; Liu et al. 2017; Song and Shao 2017). So far there is consensus among most taxonomists that the following characters are important for species separation in the family Oxytrichidae Ehrenberg, 1838: (i) body size, shape and colour; (ii) features of cortical granules; (iii) whether dorsal cilia and caudal cirri are indistinguishable or distinguishable from marginal cirri; (iv) relative length of buccal apparatus and DE value; (v) numbers and arrangement of macronuclear segments and micronuclei; (vi) ventral and dorsal ciliature; (vii) morphometric data relating to the ciliature; (viii) habitat (Song 1990; 
Song and Wilbert 1997b; Berger 1999; Foissner 1999; Song and Wilbert 2002; Küppers et al. 2011; Chen et al. 2013; Lv et al. 2013; Shao et al. 2013a, b; Singh et al. 2013; Shao et al., 2014; Wang et al. 2016; Chen et al. 2017a; Jung et al. 2017; Wang et al. 2017).

The genus Oxytricha Bory de Saint-Vincent, 1824 is one of the oldest genera of oxytrichids and so far comprises about 50 species distributed worldwide (Berger 1999; Shao et al. 2014; Foissner 2016). Some have overlapping species-level characters with respect to their living morphology, ciliature, morphometric data and habitat (Berger and Foissner 1989; Berger 1999; Foissner and Stoeck 2006; Shao et al. 2011, 2014, 2015; Méndez-Sánchez et al. 2018). Its systematics, however, has traditionally been highly confused, not least because a properly defined type species was not fixed until relatively recently (Berger 1999). The status of Oxytricha, along with three other oxytrichid genera with flexible bodies and 18 frontoventral transverse cirri, was recently reviewed by Shao et al. (2015), who defined it as follows: flexible 18 cirri oxytrichids with undulating membranes in the Oxytricha pattern and adoral zone in the shape of a question mark; frontoventral cirri in a V-shaped pattern; one left and one right marginal row; five or six dorsal kineties in the Oxytricha-pattern, that is, one or two dorsomarginal kineties and simple kinety three; fragmentation present; caudal cirri on dorsal kineties 1,2 and 4. Some molecular studies reveal that the genus is non-monophyletic ( $\mathrm{Hu}$ et al. 2011; Shao et al. 2011; Jung et al. 2017).

Oxytricha nauplia was first described from a salt soil in Greece by Berger and Foissner (1987). Later it was recorded from Costa Rica by Foissner (1997), who did not describe it. Thereafter, no redescription is available for this species so far; moreover, its morphogenetic pattern and SSU rDNA sequence data are unknown yet.

In 2016, this species was discovered in the soil biotope of northern China for the first time. Based on cultures, ontogenesis during binary fission and SSU rDNA gene sequence of the species were investigated.

\section{MATERIALS AND METHODS}

\section{Sampling and cultivation}

Oxytricha nauplia was collected from surface soil in the Kuisu Valley, Huhhot, China $\left(40^{\circ} 29^{\prime} \mathrm{N} 111^{\circ} 47^{\prime} \mathrm{E}\right)$, on 25 November 2016 , when the temperature was $5^{\circ} \mathrm{C}$, salinity 0 and $\mathrm{pH} 7.3-7.7$ (Fig. 1). Ciliates were stimulated to excyst and emerge from the soil samples by employing the non-flooded Petri dish method of Foissner et al.
(2002) in the laboratory. Isolated specimens were maintained as non-clonal cultures in Petri dishes at room temperature $\left(20^{\circ} \mathrm{C}\right)$ using Volvic natural mineral water with rice grains to enrich bacterial food organisms.

\section{Morphology}

Living cells were observed with bright-field and differential interference contrast microscopy (Luo et al. 2017). The protargol silverstaining method described by Wilbert (1975) was used to reveal the infraciliature. The protargol powder was manually synthesized, following the method previously described by Pan et al. (2013). Three voucher slides (Nos. BY201610300201, BY201610300202 and BY201610300203) with protargol stained specimens were checked to corroborate the identification and deposited in the Laboratory of Protozoology, Institute of Evolution and Marine Biodiversity, Ocean University of China. Measurements of stained specimens were carried out with an ocular micrometer (Chen et al. 2016). Drawings of stained specimens were performed at 1250 magnification with the aid of a camera lucida (Foissner 2012). Terminology and classification follows Berger (1999) and Gao et al. (2016), respectively.

\section{DNA extraction, PCR amplification and sequencing}

One or more cells were isolated from the ciliate cultures and then washed three times with sterilized fresh water $(0.22 \mu \mathrm{m}$ filtered). These cells were then transferred to a $1.5 \mathrm{ml}$ microfuge tube with a minimum volume of water. Genomic DNA of $O$. naupila was extracted using the DNeasy Blood \& Tissue kit (Qiagen) following the manufacturer's instructions (Zhao et al. 2015; Yan et al. 2016). PCR amplification of the SSU rDNA was performed as previously described (Chen et al. 2016; Huang et al. 2016), with primers 18s-F (5'-AACCTGGTTGATCCTGCCAGT-3') and 18s-R (5'-TGATCCTTCTGCAGGTTCACCTAC-3') (Medlin et al. 1988).

\section{Phylogenetic analyses}

Using the online program Muscle 3.7 (Edgar 2004), the SSU rDNA sequence of $O$. nauplia was aligned with 67 hypotrichid sequences obtained from the GenBank database. Apokeronopsis crassa (JQ424831) and Urostyla grandis (KP681648) were selected as the outgroup taxa. These sequences were edited manually using BioEdit 7.0.0 in order to remove ambiguous gaps (Hall 1999). The program MrModeltest version 2.0 (Nylander 2004) selected GTR $+\mathrm{I}$ $(50.6678)+\mathrm{G}(50.5202)$ as the best model with the Akaike information criterion, which was then used for Bayesian inference (BI) and maximum-likelihood (ML) analyses. BI analysis was performed with MrBayes 3.1.2 (Ronquist and Huelsenbeck 2003). ML trees were reconstructed using RaxML-HPC2 (Stamatakis et al. 2008) at the CIPRES website (http://www.phylo.org/). MEGA 4.0 (Tamura et al. 2007) was used to visualize tree topologies.

\section{RESULTS}

\section{Description of Chinese population of Oxytricha nau- plia (Fig. 2; Table 1)}

Body size about $85-140 \times 40-70 \mu \mathrm{m}$, mostly $130 \times$ $70 \mu \mathrm{m}$ in vivo, ca. $72-96 \times 29-55 \mu \mathrm{m}$ after protargol 


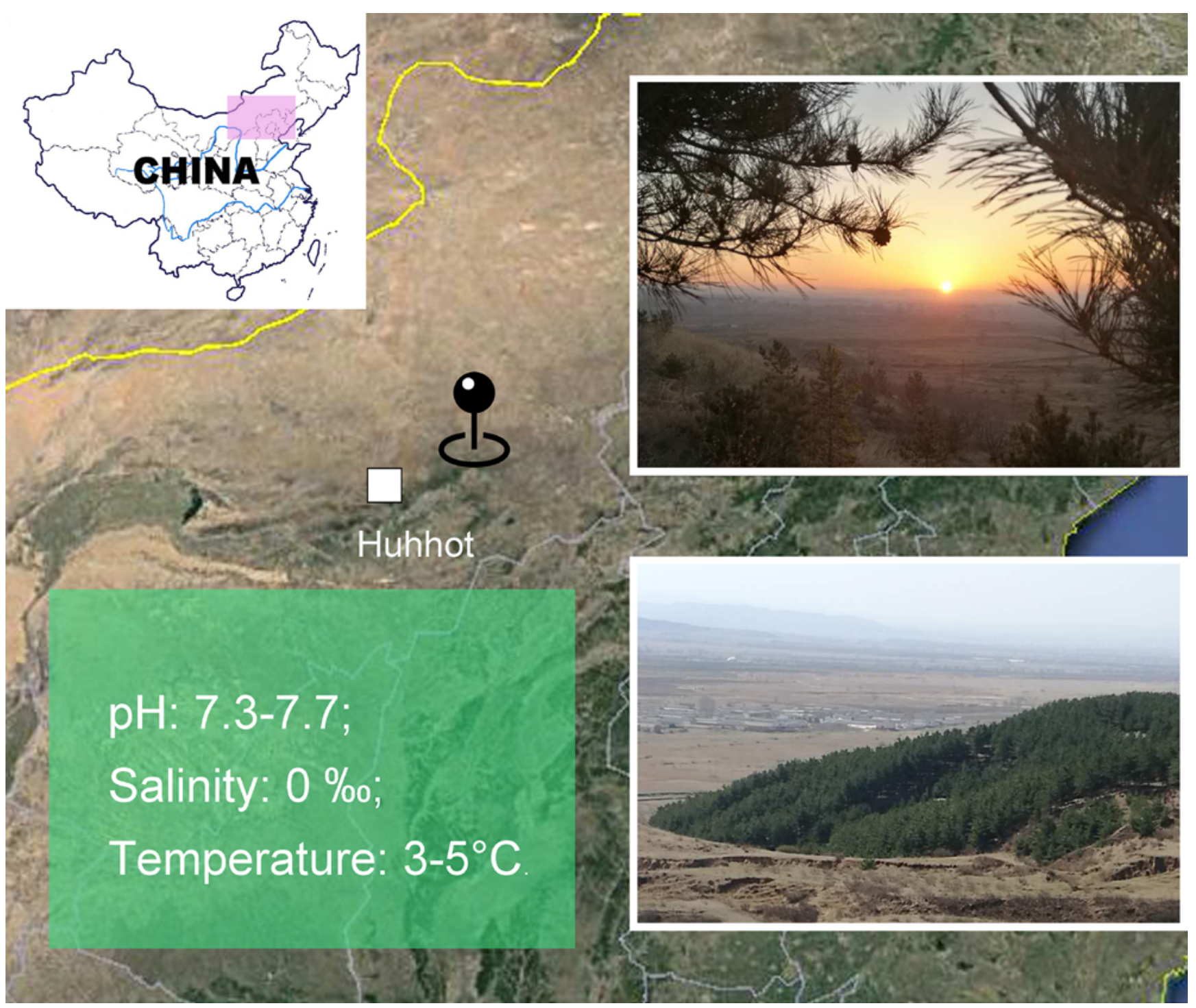

Fig. 1. Sample sites and surrounding areas.

staining (Fig. 2A, D, E-G). Body flexible but not contractile, generally elliptical, often right margin straight, left margin slightly convex at middle portion, both ends broadly rounded; sometimes plumper when well-fed; the ratio of length to width approximately $2: 1-2.5: 1$ (Fig. 2A, E-G). Dorsoventrally flattened (about 3: 1), ventral side flat, dorsal side convex in middle portion. Adoral zone of membranelles about $1 / 3$ of body length (Fig. 2A, E-G). Buccal field narrow. Pellicle thin, no cortical granules recognizable underneath. Cytoplasm colourless to greyish, containing numerous shining globules and crystals, and many lipid droplets (about
4-5 $\mu \mathrm{m}$ across), and several food vacuoles (about 5-10 $\mu \mathrm{m}$ in diameter) (Fig. 2A, E-G, I). Contractile vacuole about $15 \mu \mathrm{m}$ across, located at mid-body, near left body margin, contracting at intervals of about $30 \mathrm{~s}$ (Fig. 2A, J). Two macronuclear segments in life about $20 \times 10$ $\mu \mathrm{m}$, after protargol staining on average $15 \times 10 \mu \mathrm{m}$, usually arranged at anterior and posterior third of cell, as well as slightly left of the midline (Fig. 2A, C, H, N); distance between two segments about $7 \mu \mathrm{m}$ in protargol stained specimens. Two spherical micronuclei, each one beside macronuclear segment. Movement by rapid swimming in water or crawling on substrate. 

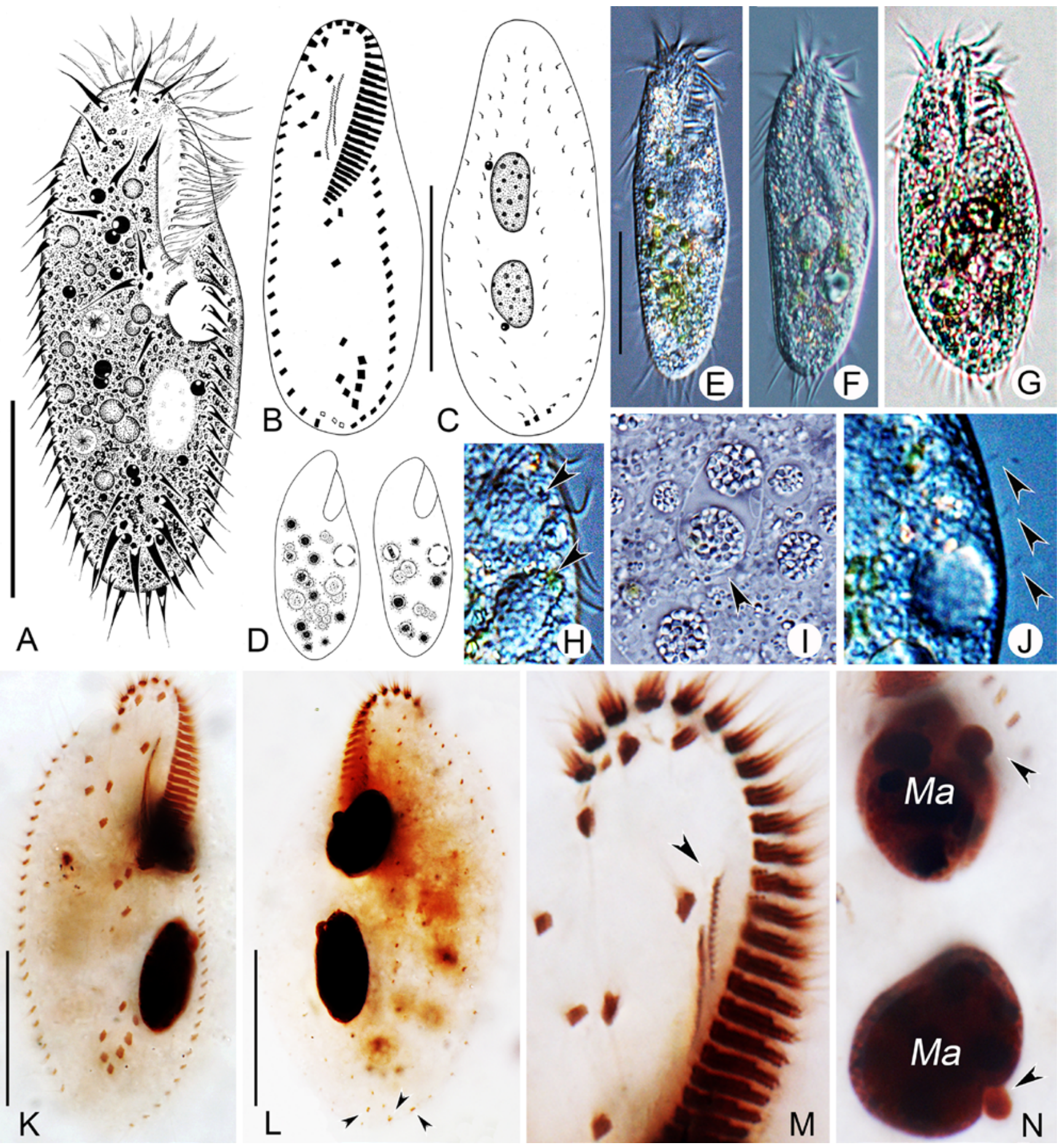

Fig. 2. Morphology of Oxytricha nauplia in vivo (A, D, E-J) and after protargol staining (B, C, K-N). (A) Ventral view of a representative individual. (B, C) Ventral (B) and dorsal (C) view of the same specimen, to show ciliature and nuclear apparatus. (D) Two different individuals to show that diversity of body shape depends on ingestion situation. (E-G) Ventral views of different individuals showing variation of body shapes. (H) Two macronuclear segments (arrowheads). (I) To show the bacterial plaques (arrowhead). (J) To show contractile vacuole and dorsal cilia (arrowheads). (K) Ventral view, to show the ciliature. (L) Dorsal view, to show the dorsal kineties, caudal cirri (arrowheads) and nuclear apparatus. (M) Magnification of the anterior ventral portion, showing the frontal, buccal, frontoventral cirri, paroral (arrowhead) and endoral membranlles. (N) Macronuclear segments and micronuclei (arrowheads). Ma, macronuclear segment. Scale bars $=45 \mu \mathrm{m}$. 
Table 1. Morphometric characterization of Oxytricha nauplia. Data based on protargol stained specimens. Measurements in $\mu \mathrm{m}$.

\begin{tabular}{|c|c|c|c|c|c|c|c|}
\hline Character & Min & Max & Mean & Median & $\mathrm{SD}$ & $\mathrm{CV}$ & $\mathrm{n}$ \\
\hline Body length & 72 & 96 & 83.6 & 86.0 & 7.98 & 9.5 & 20 \\
\hline Body width & 29 & 55 & 38.6 & 37.0 & 6.95 & 18.0 & 20 \\
\hline AZM, length & 28 & 39 & 33.3 & 32.0 & 3.37 & 10.1 & 20 \\
\hline Adoral membranelles, number & 26 & 31 & 28.7 & 29.0 & 1.17 & 4.1 & 20 \\
\hline Paroral membrane, length & 14 & 19 & 15.5 & 15.0 & 1.46 & 9.4 & 17 \\
\hline Endoral membrane, length & 11 & 19 & 16.4 & 17.0 & 1.91 & 11.6 & 17 \\
\hline Macronuclear segments, number & 2 & 2 & 2.0 & 2.0 & 0.00 & 0.0 & 20 \\
\hline Posterior Ma, length & 10 & 18 & 13.3 & 13.0 & 2.05 & 15.4 & 20 \\
\hline Posterior Ma, width & 6 & 14 & 8.3 & 8.0 & 1.71 & 20.7 & 20 \\
\hline Anterior Ma, length & 10 & 19 & 13.5 & 13.0 & 2.21 & 16.4 & 20 \\
\hline Anterior Ma, width & 5 & 12 & 7.5 & 7.0 & 1.82 & 23.9 & 20 \\
\hline Distance between two macronuclear segments & 2 & 12 & 7.4 & 7.0 & 3.01 & 41.0 & 20 \\
\hline Micronuclei, number & 1 & 2 & 1.9 & 2.0 & 0.37 & 19.8 & 20 \\
\hline Left marginal cirri, number & 13 & 21 & 18.2 & 18.0 & 1.93 & 10.2 & 19 \\
\hline Right marginal cirri, number & 14 & 25 & 21.1 & 21.0 & 2.16 & 10.6 & 19 \\
\hline Frontal cirri, number & 3 & 3 & 3.0 & 3.0 & 0.00 & 0.0 & 20 \\
\hline Buccal cirrus, number & 1 & 1 & 1.0 & 1.0 & 0.00 & 0.0 & 20 \\
\hline Frontoventral cirri, number & 4 & 4 & 4.0 & 4.0 & 0.00 & 0.0 & 20 \\
\hline PVC, number & 3 & 3 & 3.0 & 3.0 & 0.00 & 0.0 & 20 \\
\hline PTC, number & 2 & 2 & 2.0 & 2.0 & 0.00 & 0.0 & 20 \\
\hline Transverse cirri, number & 5 & 5 & 5.0 & 5.0 & 0.00 & 0.0 & 19 \\
\hline Caudal cirri, number & 2 & 3 & 2.6 & 3.0 & 0.49 & 18.6 & 17 \\
\hline Dorsal kineties, number & 6 & 6 & 6.0 & 6.0 & 0.00 & 0.0 & 20 \\
\hline Dikinetids in DK1, number & 13 & 21 & 15.8 & 16.0 & 2.16 & 13.0 & 19 \\
\hline Dikinetids in DK2, number & 12 & 20 & 16.0 & 16.0 & 2.27 & 14.2 & 13 \\
\hline Dikinetids in DK3, number & 11 & 17 & 13.7 & 13.5 & 1.90 & 13.8 & 14 \\
\hline Dikinetids in DK4, number & 5 & 7 & 6.1 & 6.0 & 0.79 & 13.0 & 12 \\
\hline Dikinetids in DK5, number & 5 & 8 & 6.7 & 7.0 & 0.96 & 14.2 & 15 \\
\hline Dikinetids in DK6, number & 2 & 5 & 3.2 & 3.0 & 0.77 & 24.2 & 15 \\
\hline
\end{tabular}

Abbreviations: $\mathrm{AZM}=$ adoral zone of membranelles; $\mathrm{CV}=$ coefficient of variation in \%; $\mathrm{DK}=$ dorsal kinety; $\mathrm{Ma}=$ macronuclear segment; $\mathrm{Max}=$ maximum; Mean = arithmetic mean; Min = minimum; $\mathrm{n}=$ number of specimens examined; $\mathrm{PTC}=$ pretransverse ventral cirri; $\mathrm{PVC}=$ postoral ventral cirri; $\mathrm{SD}=$ standard deviation.

Adoral zone composed of 26-31 membranelles (Fig. 2B, K). Paroral and endoral membranes parallel to each other; almost equal in length, the former displaced ahead of the latter (Fig. 2B, M). Three slightly enlarged frontal cirri with cilia about $15 \mu \mathrm{m}$ long in vivo, the base of right frontal cirrus near the distal end of adoral zone; single buccal cirrus near anterior end of paroral membrane. Invariably four frontoventral cirri, of which the cirri $\mathrm{VI} / 4, \mathrm{VI} / 3$ and $\mathrm{IV} / 3$ are arranged in a somewhat oblique row; cirrus III/2 close to and left of cirrus $\mathrm{VI} / 3$ inserted between the cirri $\mathrm{VI} / 4$ and $\mathrm{IV} / 3$ (Fig. 2B, K). Three postoral ventral cirri immediately behind buccal vertex, cirrus $\mathrm{V} / 4$ closer to cirrus $\mathrm{IV} / 2$ than cirrus V/3 (Fig. 2A, B, K). Five slightly enlarged transverse cirri in a hook-shaped row, in life about 20 $\mu \mathrm{m}$ long, displaced slightly anteriad, which render them project beyond posterior end of cell; two pretransverse ventral cirri typical in oxytrichid ciliates, cirrus $\mathrm{VI} / 2$ located near rightmost transverse cirrus, cirrus V/2 located ahead of transverse cirri; distance between cirri 
$\mathrm{V} / 3$ and $\mathrm{V} / 4$ smaller than that between cirri $\mathrm{V} / 3$ and $\mathrm{V} / 2$ (Fig. 2B, K). Both marginal rows terminated at rear end of cell but non-confluent posteriorly; left row composed of 13-21 cirri, right row with 14-25 cirri; cilia of marginal cirri in life about $15 \mu \mathrm{m}$ long (Fig. 2A, E-G).

Constantly six dorsal kineties (Fig. 2C, L); leftmost two (dorsal kineties 1 and 2) almost bipolar, each comprising about 12-21 pairs of basal bodies; dorsal kineties 3 and 5 starting at about the anterior end of cell and ending at $4 / 5$ and $2 / 5$ of cell length, respectively; kinety 4 commencing below tail end of dorsal kinety 5 and stretching to the posterior end of cell; dorsal kinety 6 located anterior right of dorsal kinety 5 , composed of two to five pairs of basal bodies (Fig. 2C, L). Dorsal cilia about $3 \mu \mathrm{m}$ long in vivo. Three thin caudal cirri, located at the posterior body margin, slightly separated, one each on dorsal kineties 1, 2 and 4 (Fig. 2C, L).

\section{Morphogenesis}

\section{Stomatogenesis}

Stomatogenesis begins with the apokinetal proliferation of groups of closely spaced basal bodies behind the cirrus V/3 and left of transverse cirri (Fig. 3A). These groups subsequently merge by further proliferation of basal bodies (Fig. 3B), and form a single anarchic field that is the oral primordium of opisthe (OP; Fig. 3C). During the formation of the OP, parental cirri nearby apparently remain unchanged and thus do not contribute to this process except for the cirrus IV/2. Next, a threadlike anlage, which is the undulating membranes anlage (UMA), is detached from the right of the OP. The remaining part of the OP begins to develop new membranelles posteriad and from right to left (Fig. 3D, F). Meanwhile, the old undulating membranes dedifferentiate to form the UMA for the proter (Fig. 3D). At late stages, a frontal cirrus is developed from the anterior end of the UMA, and paroral and endoral membranes are formed by longitudinal splitting of the remaining UMA in both proter and opisthe (Figs 3D, 4A, 5J).

\section{Development of frontoventral-transverse cirri}

Probably, the development of frontoventral-transverse cirral anlagen (FVT anlagen) begins with the de novo proliferation of a group of basal bodies on the right of postoral ventral cirrus $\mathrm{V} / 4$ (Figs 3B-C, 5B). Later, the postoral ventral cirri $V / 3$ and $V / 4$ disappear and soon the FVT anlagen are formed as five streaks in the opisthe with the joining of some de novo formed kinetosomes. At the same time, five streaks of FVT-anlagen are formed in the proter while cirri II/2, III/2 and
IV/3 vanish away. The formation of each streak is hard to confirm owing to the lack of several critical stages, but in consideration of the position of streaks, origin or fate of some certain cirri can be deduced as follows: (i) the left streaks of FVT anlagen of opisthe occur independently; (ii) the cirri II/2, III/2 and IV/3 conceivably dedifferentiate and participate in the formation of anlagen of proter; (iii) cirri $\mathrm{VI} / 4$ and $\mathrm{VI} / 3$ never contribute to anlagen formation (Figs 3D, F, 5C, D, J). With the UMA (anlage I) included, six FVT-anlagen (I-VI counted from left to right) are generated.

Next, these cirral anlagen then broaden, break apart and migrate to their final positions as distinct cirri. Anlagen I-VI generate the following numbers of cirri: 1,3 , $3,3,4,4$, and a total of 18 cirri will be formed for both proter and opisthe: three frontal cirri originate from anlagen I (1), II (3) and III (3); the buccal cirrus develops from anlage II (2); four frontoventral cirri are formed from anlagen III (2), IV (3), VI (3) and VI (4); three postoral ventral cirri develop from anlagen IV (2), V (3) and $\mathrm{V}(4)$; two pretransverse ventral cirri derive from V (2) and VI (2); and five transverse cirri come from each of anlagen II-VI (1) (Figs 3D, F, 4A, 5C-E, J).

\section{Development of marginal rows}

Both left and right marginal anlagen develop within the parental rows. The marginal anlagen are built by basal bodies derived from the dedifferentiation of parental marginal cirri. Notably, the right marginal anlagen develop much earlier than the left ones (Fig. 3D-F). Finally, in both proter and opisthe, the anlagen of the marginal cirral rows develop intrakinetally, lengthen longitudinally and replace the parental ones (Fig. 4A, C, E).

\section{Development of dorsal kineties}

New dorsal kineties originate from two groups of dorsal anlagen in both proter and opisthe that then proliferate, lengthen at both ends and replace the parental structures at the late stage. The first group develops intrakinetally within parental dorsal kineties $1-3$, which at first consists of only three anlagen in both proter and opisthe (Fig. 3E, G). In middle and late dividers, the rightmost one splits into two parts in the posterior region to form the new dorsal kineties 3 and 4, and one caudal cirrus is generated at each posterior end of the new dorsal kineties 1, 2 and 4 (Fig. 4B, D). Meanwhile, two small anlagen originate at the anterior end of the right marginal cirral row (Figs 4A; 5E) and finally develop into the dorsomarginal kineties 5 and 6 in each divider (Fig. 4D, F). 


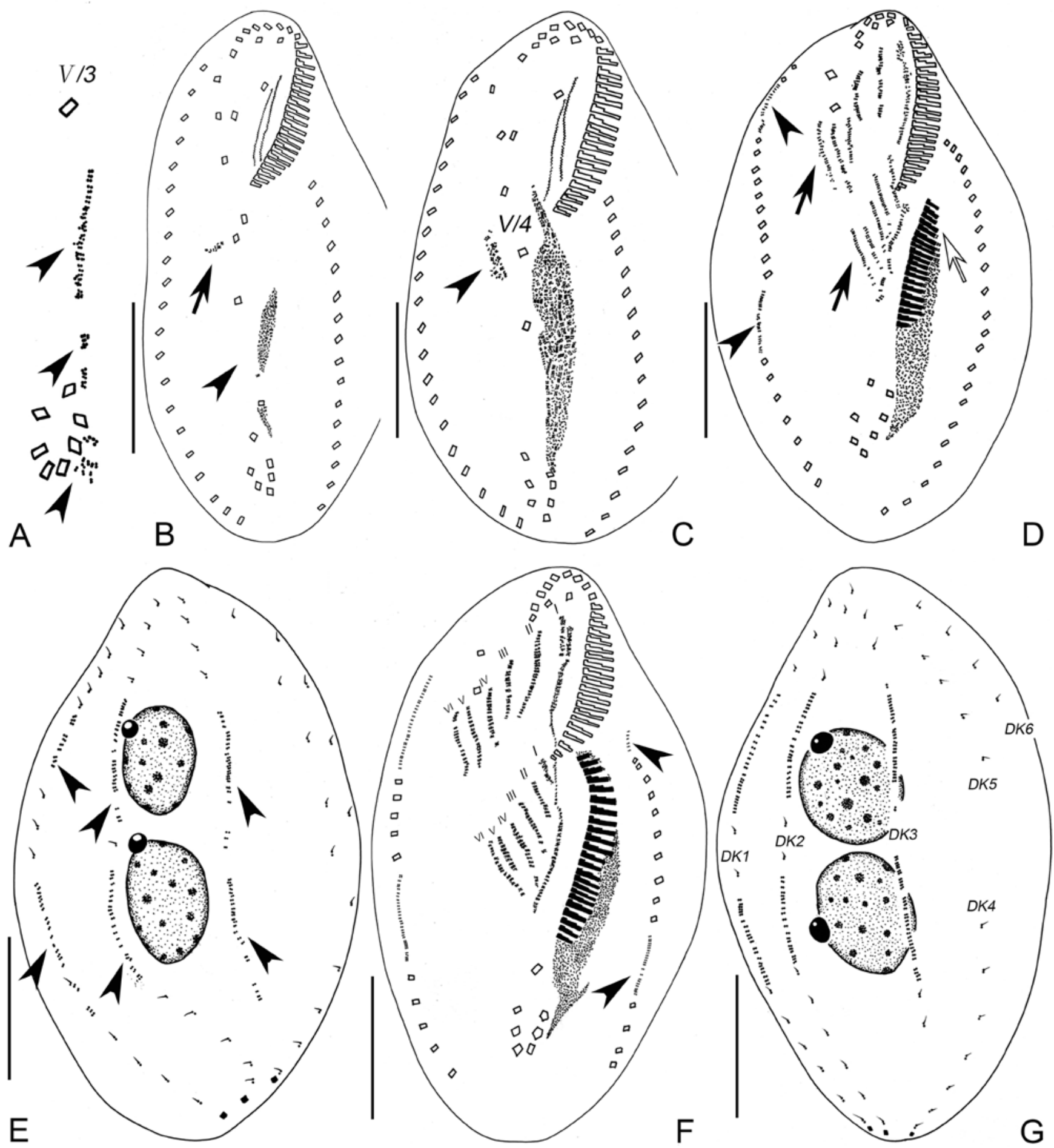

Fig. 3. A-G. Morphogenesis of Oxytricha nauplia after protargol staining. (A) A section of ventral side of an early divider to show the three parts of oral primordium (arrowheads). (B) Ventral view of an early divider to show that basal bodies in oral primordium start mixing together (arrowhead) and a little group of basal bodies formed de novo at the right of postoral ventral cirrus V/4 (arrow). (C) Ventral view of an early divider to show the cirrus IV/2 is disorganized and the basal bodies at the right of postoral ventral cirrus $\mathrm{V} / 4$ are proliferated into a larger region (arrowhead). (D, E) Ventral and dorsal views of the same specimen, arrows in D show the frontoventral-transverse cirral anlage arisen, arrowheads show that the right marginal anlage of the opisthe and proter, and hollow arrow depicts the newly formed membranelles; arrowheads in E show dorsal kineties anlagen. (F, G) Ventral and dorsal views of the same specimen, showing the 6 streaks of frontoventral-transverse cirral anlage, arrowheads show the left marginal anlage of the opisthe and proter. DK, dorsal kinety; I to VI represent anlagen I to VI. Scale bars $=30 \mu \mathrm{m}$. 

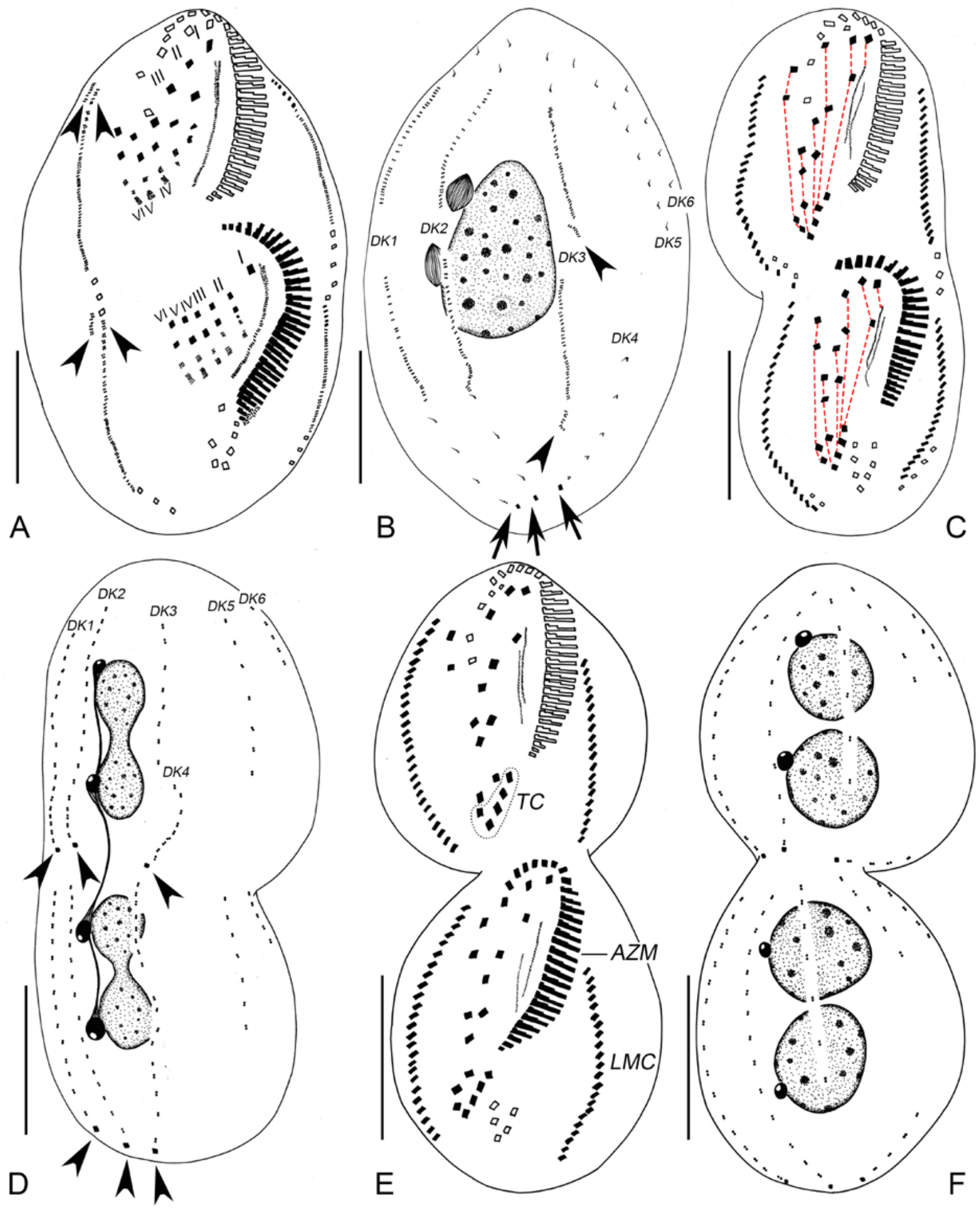

Fig. 4. A-F. Morphogenesis of Oxytricha nauplia after protargol staining. (A, B) Ventral and dorsal views of the same mid-divider, arrowheads in A mark the dorsomarginal kineties anlagen and in B show the posterior fragmentation of the third dorsal kinety anlage (counted from left to right), arrows in B show the old caudal cirri. (C, D) Ventral and dorsal views of the same late divider, (C) shows the completely formed frontoventral-transverse cirri and (D) shows the caudal cirri (arrowheads). (E, F) Ventral and dorsal views of the same late divider just before cell division, to show the newly built ciliature and nuclear apparatus. AZM = adoral zone of membranelles; DK1, 2, 3, 4, 5 = dorsal kinety $1,2,3,4,5 ; \mathrm{LMC}=$ left marginal cirri; $\mathrm{TC}=$ transverse cirri; I to VI represent anlagen I to VI. Scale bars $=30 \mu \mathrm{m}$. 


\section{Division of nuclear apparatus}

The nuclear apparatus divides in the usual way for hypotrich ciliates. Two macronuclear segments fuse with each other and eventually form a single structure that subsequently divides twice (Figs 4B, D, 5G, J). In the final stages, with the separation of two daughter cells, there are two macronuclear segments per daughter cell (Fig. 4F). The micronuclei undergo mitotic division as usual (Figs 4B, D, F, 5J).

\section{Sequence comparison and phylogenetic analyses}

The SSU rDNA sequence of our Oxytricha nauplia isolate was deposited in GenBank with accession number MH035977. Its length and $\mathrm{G}+\mathrm{C}$ content were 1728 bp and $45.72 \%$, respectively. O. nauplia differs from its congeners by $12-66 \mathrm{bp}$ (Table 2). The topologies of the $\mathrm{ML}$ and $\mathrm{BI}$ trees were similar, therefore only the ML tree is shown (Fig. 6). Oxytricha nauplia groups with $O$. paragranulifera with high supported value (98ML/1.00BI) and occupies an isolated position, and then nests in a high supported clade including Onychodromopsis flexilis, Rigidothrix goiseri, Paroxytricha ottowi and Paroxytricha longigranulosa.

\section{DISCUSSION}

\section{Morphological comparison of Chinese population with original description and other similar forms}

The current ciliate was identified as Oxytricha nauplia because it resembles the original population in the following diagnostic features, i.e. medium-sized and nearly parallel-sided body, two macronuclear segments and two micronuclei, almost similar cirral pattern, and the lack of cortical granules (Berger and Foissner 1987). Nevertheless, the former is somewhat larger in vivo $(85-140 \times 40-70 \mu \mathrm{m}$ vs. $80-100 \times 40 \mu \mathrm{m})$ and the number of caudal cirri in it is consistently 3 (vs. 3-4). The frontoventral cirri of Chinese population are arranged

Table 2. Pairwise blast of SSU rDNA sequences for 9 species of Oxytricha and 2 species of Paroxytricha shown in Fig. 6, indicating the sequence similarity of any two species. The numbers in parentheses presents the base variations between the two blasted sequences.

\begin{tabular}{|c|c|c|c|c|c|c|c|c|c|c|c|}
\hline $\begin{array}{l}\text { Identity value } \\
(\%[\mathrm{bp}])\end{array}$ & 1 & 2 & 3 & 4 & 5 & 6 & 7 & 8 & 9 & 10 & 11 \\
\hline 1 & $\begin{array}{l}100.00 \\
(0)\end{array}$ & $\begin{array}{l}98.83 \\
(20)\end{array}$ & $\begin{array}{l}97.17 \\
(49)\end{array}$ & $\begin{array}{l}96.18 \\
(66)\end{array}$ & $\begin{array}{l}97.22 \\
(48)\end{array}$ & $\begin{array}{l}96.48 \\
(61)\end{array}$ & $\begin{array}{l}96.48 \\
(61)\end{array}$ & $\begin{array}{l}98.43 \\
(27)\end{array}$ & $\begin{array}{l}97.38 \\
(42)\end{array}$ & $\begin{array}{l}99.01 \\
(17)\end{array}$ & $\begin{array}{l}99.31 \\
(12)\end{array}$ \\
\hline 2 & $\begin{array}{l}98.83 \\
(20)\end{array}$ & $\begin{array}{l}100.00 \\
(0)\end{array}$ & $\begin{array}{l}96.08 \\
(67)\end{array}$ & $\begin{array}{l}95.09 \\
(84)\end{array}$ & $\begin{array}{l}96.14 \\
(66)\end{array}$ & $\begin{array}{l}95.39 \\
(79)\end{array}$ & $\begin{array}{l}95.39 \\
(79)\end{array}$ & $\begin{array}{l}97.37 \\
(45)\end{array}$ & $\begin{array}{l}96.14 \\
(61)\end{array}$ & $\begin{array}{l}97.95 \\
(35)\end{array}$ & $\begin{array}{l}98.25 \\
(30)\end{array}$ \\
\hline 3 & $\begin{array}{l}97.17 \\
(49)\end{array}$ & $\begin{array}{l}96.08 \\
(67)\end{array}$ & $\begin{array}{l}100.00 \\
(0)\end{array}$ & $\begin{array}{l}97.85 \\
(38)\end{array}$ & $\begin{array}{l}98.38 \\
(28)\end{array}$ & $\begin{array}{l}97.86 \\
(38)\end{array}$ & $\begin{array}{l}97.86 \\
(38)\end{array}$ & $\begin{array}{l}97.17 \\
(49)\end{array}$ & $\begin{array}{l}96.36 \\
(59)\end{array}$ & $\begin{array}{l}96.99 \\
(52)\end{array}$ & $\begin{array}{l}97.24 \\
(49)\end{array}$ \\
\hline 4 & $\begin{array}{l}96.18 \\
(66)\end{array}$ & $\begin{array}{l}95.09 \\
(84)\end{array}$ & $\begin{array}{l}97.85 \\
(38)\end{array}$ & $\begin{array}{l}100.00 \\
(0)\end{array}$ & $\begin{array}{l}97.10 \\
(50)\end{array}$ & $\begin{array}{l}97.23 \\
(49)\end{array}$ & $\begin{array}{l}97.23 \\
(49)\end{array}$ & $\begin{array}{l}96.41 \\
(62)\end{array}$ & $\begin{array}{l}96.18 \\
(62)\end{array}$ & $\begin{array}{l}95.90 \\
(71)\end{array}$ & $\begin{array}{l}96.17 \\
(68)\end{array}$ \\
\hline 5 & $\begin{array}{l}97.22 \\
(48)\end{array}$ & $\begin{array}{l}96.14 \\
(66)\end{array}$ & $\begin{array}{l}98.38 \\
(28)\end{array}$ & $\begin{array}{l}97.10 \\
(50)\end{array}$ & $\begin{array}{l}100.00 \\
(0)\end{array}$ & $\begin{array}{l}97.86 \\
(37)\end{array}$ & $\begin{array}{l}97.86 \\
(37)\end{array}$ & $\begin{array}{l}96.88 \\
(54)\end{array}$ & $\begin{array}{l}96.68 \\
(53)\end{array}$ & $\begin{array}{l}96.88 \\
(54)\end{array}$ & $\begin{array}{l}97.11 \\
(50)\end{array}$ \\
\hline 6 & $\begin{array}{l}96.48 \\
(61)\end{array}$ & $\begin{array}{l}95.39 \\
(79)\end{array}$ & $\begin{array}{l}97.86 \\
(38)\end{array}$ & $\begin{array}{l}97.23 \\
(49)\end{array}$ & $\begin{array}{l}97.86 \\
(37)\end{array}$ & $\begin{array}{l}100.00 \\
(0)\end{array}$ & $\begin{array}{l}100.00 \\
(0)\end{array}$ & $\begin{array}{l}96.65 \\
(58)\end{array}$ & $\begin{array}{l}96.12 \\
(63)\end{array}$ & $\begin{array}{l}96.25 \\
(65)\end{array}$ & $\begin{array}{l}96.52 \\
(62)\end{array}$ \\
\hline 7 & $\begin{array}{l}96.48 \\
(61)\end{array}$ & $\begin{array}{l}95.39 \\
(79)\end{array}$ & $\begin{array}{l}97.86 \\
(38)\end{array}$ & $\begin{array}{l}97.23 \\
(49)\end{array}$ & $\begin{array}{l}97.86 \\
(37)\end{array}$ & $\begin{array}{l}100.00 \\
(0)\end{array}$ & $\begin{array}{l}100.00 \\
(0)\end{array}$ & $\begin{array}{l}96.65 \\
(58)\end{array}$ & $\begin{array}{l}96.12 \\
(63)\end{array}$ & $\begin{array}{l}96.25 \\
(65)\end{array}$ & $\begin{array}{l}96.52 \\
(62)\end{array}$ \\
\hline 8 & $\begin{array}{l}98.43 \\
(27)\end{array}$ & $\begin{array}{l}97.37 \\
(45)\end{array}$ & $\begin{array}{l}97.17 \\
(49)\end{array}$ & $\begin{array}{l}96.41 \\
(62)\end{array}$ & $\begin{array}{l}96.88 \\
(54)\end{array}$ & $\begin{array}{l}96.65 \\
(58)\end{array}$ & $\begin{array}{l}96.65 \\
(58)\end{array}$ & $\begin{array}{c}100.00 \\
(0)\end{array}$ & $\begin{array}{l}97.50 \\
(40)\end{array}$ & $\begin{array}{l}98.21 \\
(31)\end{array}$ & $\begin{array}{l}98.38 \\
(28)\end{array}$ \\
\hline 9 & $\begin{array}{l}97.38 \\
(42)\end{array}$ & $\begin{array}{l}96.14 \\
(61)\end{array}$ & $\begin{array}{l}96.36 \\
(59)\end{array}$ & $\begin{array}{l}96.18 \\
(62)\end{array}$ & $\begin{array}{l}96.68 \\
(53)\end{array}$ & $\begin{array}{l}96.12 \\
(63)\end{array}$ & $\begin{array}{l}96.12 \\
(63)\end{array}$ & $\begin{array}{l}97.50 \\
(40)\end{array}$ & $\begin{array}{c}100.00 \\
(0)\end{array}$ & $\begin{array}{l}97.00 \\
(48)\end{array}$ & $\begin{array}{l}97.17 \\
(46)\end{array}$ \\
\hline 10 & $\begin{array}{l}99.01 \\
(17)\end{array}$ & $\begin{array}{l}97.95 \\
(35)\end{array}$ & $\begin{array}{l}96.99 \\
(52)\end{array}$ & $\begin{array}{l}95.90 \\
(71)\end{array}$ & $\begin{array}{l}96.88 \\
(54)\end{array}$ & $\begin{array}{l}96.25 \\
(65)\end{array}$ & $\begin{array}{l}96.25 \\
(65)\end{array}$ & $\begin{array}{l}98.21 \\
(31)\end{array}$ & $\begin{array}{l}97.00 \\
(48)\end{array}$ & $\begin{array}{c}100.00 \\
(0)\end{array}$ & $\begin{array}{l}99.60 \\
(7)\end{array}$ \\
\hline 11 & $\begin{array}{l}99.31 \\
(12)\end{array}$ & $\begin{array}{l}98.25 \\
(30)\end{array}$ & $\begin{array}{l}97.24 \\
(49)\end{array}$ & $\begin{array}{l}96.17 \\
(68)\end{array}$ & $\begin{array}{l}97.11 \\
(50)\end{array}$ & $\begin{array}{l}96.52 \\
(62)\end{array}$ & $\begin{array}{l}96.52 \\
(62)\end{array}$ & $\begin{array}{l}98.38 \\
(28)\end{array}$ & $\begin{array}{l}97.17 \\
(46)\end{array}$ & $\begin{array}{l}99.60 \\
(7)\end{array}$ & $\begin{array}{c}100.00 \\
(0)\end{array}$ \\
\hline
\end{tabular}

1. Oxytricha nauplia (MH035977) 2. Oxytricha paragranulifera (KJ081200) 3. Oxytricha sp. (AF164683) 4. Oxytricha ferruginea (AF370027) 5. Oxytricha sp. Oc (FN429123) 6. Oxytricha trifallax (AF164121) 7. Oxytricha sp. Aspen (AF164126) 8. Oxytricha elegans (AM412767) 9. Oxytricha granulifera (KJ081199) 10. Paroxytricha ottowi (JQ723977) 11. Paroxytricha longigranulosa (JX899420). 


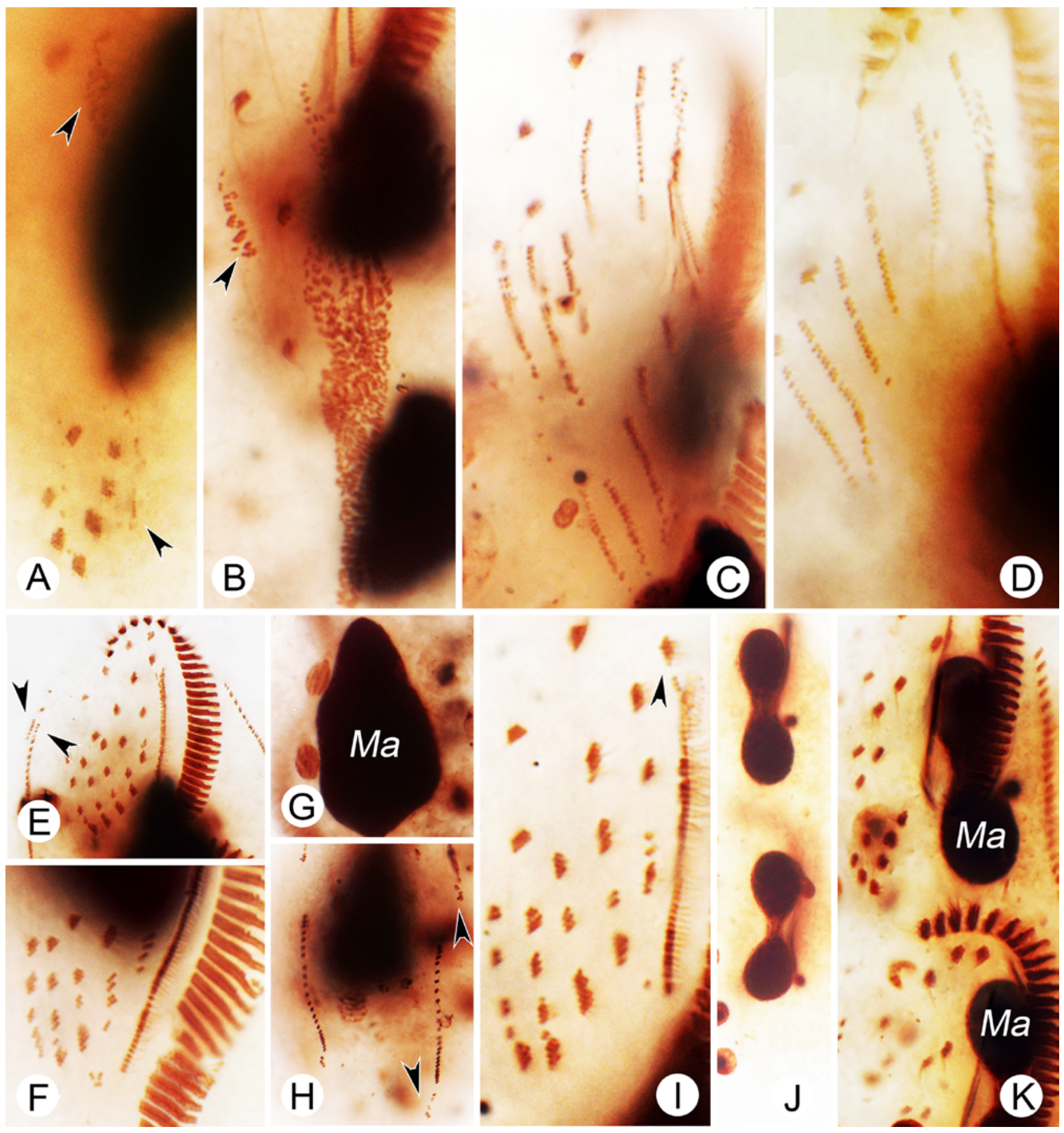

Fig. 5. Magnified photomicrographs of Oxytricha nauplia after protargol staining. (A) Ventral view of an early divider to show the three parts of oral primordium (arrowheads). (B) Ventral view of an early divider to show the cirrus IV/2 is disorganized and the basal bodies at the right of postoral ventral cirrus V/4 proliferated into a larger region (arrowhead). (C) Ventral view of an early middle divider, showing the frontoventral-transverse cirral anlage arisen. (D) Ventral view of a middle divider, showing the six streaks of the frontoventral-transverse cirral anlagen of proter. (E, F, G, H) Same specimen of a middle divider. (E) Ventral view of the anterior portion, showing unitized frontal-ventral-transverse cirri anlagen and the dorsomarginal kineties anlagen (arrowheads) in proter. (F) Ventral view of adoral zone of the opisthe, showing the frontal-ventral-transverse cirri of the opisthe. $(\mathrm{G}, \mathrm{H})$ Showing the fused macronucleus and the dividing micronuclei, arrowheads show the posterior fragmentation of the third dorsal kinety analge. (I) Another middle divider, arrowhead shows the anlage of cirrus I at the anterior end of undulating membranes anlagen. $(\mathbf{J}, \mathbf{K})$ The same specimen, showing the dividing of nuclear apparatus and ventral ciliature. $\mathrm{Ma}=$ macronuclear segments. 


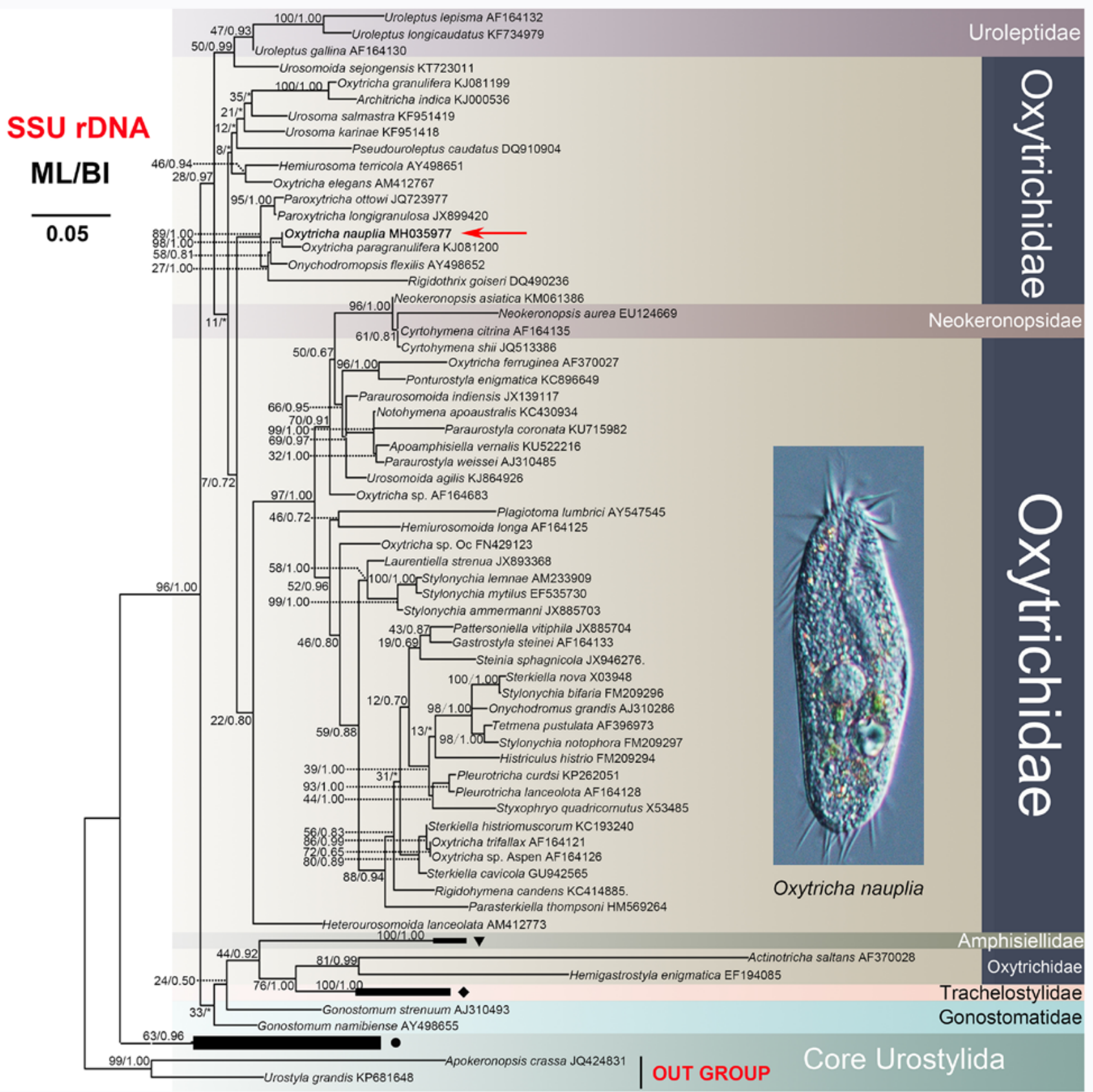

Fig. 6. Maximum likelihood (ML) phylogenetic tree inferred from SSU rDNA sequences of 70 hypotrichs, and phylogenetic position of Oxytricha nauplia (red arrow). Black circle indicates four SSU rDNA sequences that include Uroleptopsis citrina (FJ870094), Nothoholosticha fasciola (FJ377548), Heterokeronopsis pulchra (JQ083600) and Anteholosticha monilata (KJ958488). Black triangle represents two SSU rDNA sequences that include Protogastrostyla sterkii (FJ870099) and Protogastrostyla pulchra (EF194082). Black square indicates two Trachelostylidae SSU rDNA sequences: Spirotrachelostyla tani (FJ870093) and Trachelostyla pediculiformis (DQ057346). Disagreement between ML and BI (*). 
in typical Oxytricha pattern, that is, III/2 located left and slightly ahead of VI/3, both are between VI/4 and $\mathrm{IV} / 3$, however the original isolate was described as non-Oxytricha pattern in Berger and Foissner (1997). After rechecking the types of this species, we found that the cirri $\mathrm{VI} / 4$ and $\mathrm{VI} / 3$ were misinterpreted as III/3 and $\mathrm{VI} / 4$, respectively, and a spot or fibre agglomerate was described as cirrus $\mathrm{VI} / 3$ in the holotype (Fig. 7A-E). This pattern was clearly demonstrated in other paratypes (Fig. 7F). In addition, five dorsal kineties was described in original description because commencing of dorsal kinety 4 was close to terminal of kinety 5 (Fig. 7G; Berger 1999). However, two anlagen of dorsomarginal kinety in morphogenesis as shown in the present study confirmed that the dorsal kineties were numbered six rather than five.

Given the similar body shape, body length in life usually less than $150 \mu \mathrm{m}$, ciliature in a typical $O x y$ tricha-pattern, nuclear apparatus, 13 morphologically similar forms should be compared with Oxytricha nauplia, namely $O$. chlorelligera Kahl, 1932, O. granulifera Foissner and Adam, 1983, O. granulosa Schmitz, 1986, O. lithofera Foissner, 2016, O. oxymarina Berger, 1999, O. paragranulifera Shao et al., 2014, O. procera Kahl, 1932, O. proximate Shibuya, 1930, O. pseudosimilis Hemberger, 1985, O. pulvillus Foissner, 2016, O. tenella Song and Wilbert, 1989, Paroxytricha ottowi
(Foissner, 1997) Foissner, 2016 and P. longigranulosa (Berger and Foissner, 1989) Foissner, 2016.

Of these species, Oxytricha paragranulifera and $O$. granulifera have a very similar body size and shape to $O$. nauplia, but the first two species can be distinguished from $O$. nauplia by having cortical granules (vs. absence). Furthermore, the macronuclear segments of $O$. paragranulifera are adjacent (vs. obviously detached in $O$. nauplia). In addition, $O$. granulifera differs from $O$. nauplia by having five or six dorsal kineties (vs. six) (Shao et al. 2014).

Oxytricha pseudosimilis resembles $O$. nauplia in body size but differs by having just five dorsal kineties, longer dorsal cilia ( $8 \mu \mathrm{m}$ vs. $2-3 \mu \mathrm{m}$ ), and the position of cirrus III/2 (below the cirrus VI/ 3 vs. at the same level) (Berger 1999).

Oxytricha tenella is smaller (50-70 $\mu \mathrm{m}$ vs. $85-140$ $\mu \mathrm{m}$ ) and has cortical granules (vs. absence cortical granules) and different arrangement of frontoventral cirri, and thus cannot be confused with $O$. nauplia (Berger 1999).

Both Oxytricha lithoffera and $O$. pulvillus are relatively smaller (60-85 $\mu \mathrm{m}$ long and $80-100 \mu \mathrm{m}$ long, respectively); moreover, the former has two conspicuous lithosomes, and the latter possesses a preoral cushion and regularly arranged cortical granules (Foissner 2016), all these features are lacking in O. nauplia.
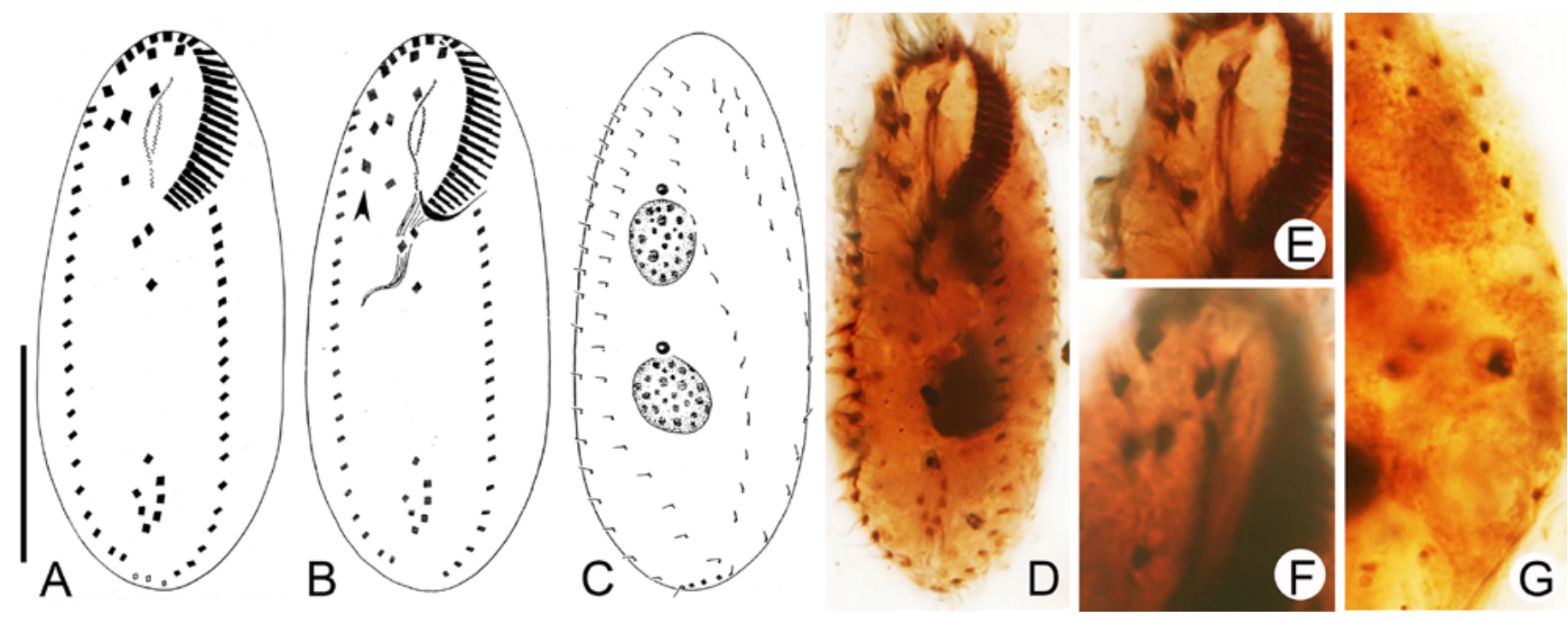

Fig. 7. Drawings (A-C) and photomicrographs (D-G) of original population of Oxytricha nauplia after protargol staining. (A) Ventral ciliature (redrawing from the holotype). (B, C) Ventral (B) and dorsal (C) views of the holotype from Berger (1999), arrowhead shows a misinterpreted frontoventral cirrus. (D) Ventral ciliature of the holotype. (E) Magnification of frontoventral cirri of the holotype. (F) Ventral view of the anterior portion of a paratype, to show the arrangement of frontoventral cirri. (G) Dorsal view of the right portion of another paratype, to show dorsal kineties 5 and 6. 
Therefore, these two species cannot be confused with O. nauplia.

Oxytrich a procera differs from Oxytricha nauplia in body shape (4-6 times as long as broad vs. 2-2.5 times in $O$. nauplia) and the position of contractile vacuole (in front of mid-body vs. mid-body) (Berger 1999).

Oxytricha oxymarina can be distinguished from $O$. nauplia in having three bipolar dorsal kineties (vs six dorsal kineties, four of which are not bipolar), and an adoral zone that is rather long relative to the body length (51\% vs. 37\% after protargol staining) (Berger 1999).

Oxytricha granulosa differs from O. nauplia in a larger body size $(155-280 \mu \mathrm{m}$ vs. $85-140 \mu \mathrm{m})$, five dorsal kineties (vs. six) and having cortical granules (vs. absence) (Berger 1999).

Oxytricha chlorelligera has a similar body shape and ciliature to $O$. nauplia, but differs by possessing symbiotic algae (vs. absent) (Berger 1999).

Paroxytricha ottowi is also very similar to O. nauplia in terms of body size, six dorsal kineties, but mainly differs by having eight macronuclear segments (vs. two segments) and cortical granules (vs. absence) (Foissner 1997).

Paroxytricha longigranulosa resembles $O$. nauplia in its dorsal ciliature; however, the former can be distinguished by the presence (vs. absence) of cortical granules (Foissner 2016).

\section{Morphogenesis}

So far morphogenetic data are available for very few species in the genus Oxytricha, which, however, reveals diverse patterns (Berger 1999; Shao et al. 2015; Foissner 2016; Méndez-Sánchez et al. 2018). Formation of each streak is hard to confirm because of the lack of some critical stages. However, according to position of streaks we considered that in Oxytricha nauplia anlagen IV and VI of proter are probably formed de novo as shown in O. pulvillus Foissner, 2016, while in $O$. granulifera, this anlage originates from the postoral ventral cirrus $\mathrm{V} 3$. The anlage $\mathrm{V}$ of proter originates from the frontoventral cirrus IV/3 in O. nauplia, while from V/4 in $O$. granulifera. The origin of the anlage V of opisthe and participation of cirrus V/3 cannot be deduced in O. nauplia. . Based on data available (Foissner and Adam 1983), it may be derived from the postoral ventral cirrus or newly formed. Oxytricha nauplia has the same origin of oral primordium as in O. granulifera and $O$. pulvillus in which oral primordium begins with proliferation of basal bodies between cirrus $\mathrm{V} / 3$ and cirrus V/2 (Foissner 2016; Méndez-Sánchez et al. 2018).
Dorsal morphogenesis proceeds in Oxytricha pattern, that is, kinety 3 fragments into two parts, the posterior one becoming kinety 4 . This type can be found in $O$. granulifera, $O$. acidotolerans, $O$. pulvillus and Allotricha, Notohymena, Rygidohymena, Cyrtohymena, Sterkiella, Stylonychia, Gastrostyla (Berger 1999; Shi et al. 2002; Chen et al. 2013; Lv et al. 2013; Singh et al. 2013; Weisse et al. 2013; Chen et al. 2015; Hu and Kusuoka 2015; Kumar et al. 2015; Chen et al. 2016; Foissner 2016; Kumar and Foissner 2017; Luo et al. 2017); whereas species in Urosomoida, Urosoma and Parasterkiella lack dorsal kinety 3 fragmentation (Berger 1999; Küppers et al. 2011).

Like Oxytricha pulvillus, O. nauplia consistently develops two anlagen to the anterior right and front of the right marginal row anlage, which give rise to two dorsomarginal kineties in interphase specimens (Foissner 2016), while $O$. granulifera forms one or two dorsomarginal kineties anlagen (Berger 19999; Méndez-Sánchez et al. 2018).

The anterior end of dorsal kinety 4 and the posterior end of dorsal kinety 5 are almost confluent in vegetative cells of $O$. nauplia, which might be the reason that Berger and Foissner (1987) regarded them as one dorsal kinety. Based on investigation of middle-late dividers, the origin of these two kineties is revealed.

Generally speaking, paroral and endoral membranes in Oxytricha spp. are arranged in two ways, that is Oxytricha-pattern (both membranes are curved and intersected spatially) and Stylonychia-pattern (two membranes nearly straight and parallel to each other) (Berger and Foissner 1997; Berger 1999; Shao et al. 2011, 2014, 2015). This character is important to identify oxytrichids to the species level, and even discriminate among genera, but it must be considered carefully because an impregnation procedure could alter the arrangement. This could lead to the correct pattern being overlooked. But among the morphogenesis it is certain that $O$. nauplia has a Stylonychia-pattern.

\section{Phylogenetic analyses}

As shown in the SSU rDNA trees, Oxytricha nauplia has a closer relationship with $O$. paragranulifera, which is in accordance with morphological similarity of both species (e.g. flexible body, medium cell size, the number of adoral membranelles, the arrangement of frontoventral cirri, undulating membranes in Stylonychia-pattern, two macronuclear segments and two micronuclei, six dorsal kineties, soil biotope). Onychodromopsis flexilis differs from these two species in the frontal ciliature 
(non-Oxytricha pattern vs. Oxytricha pattern) and more than one marginal row on each side (vs. consistently one row), so the possible reason to explain the grouping of these three species is that they have medium-sized, flexible body and two macronuclear segments. The former two characters, however, cannot explain the clustering of Rigidothrix goiseri in maximum supported $\mathrm{BI}$ tree because $R$. goiseri is big (average size $230 \times$ $70 \mu \mathrm{m}$ ), and has rigid pellicle and ventral cirri in Uroleptus pattern, and undulating membranes in Oxytricha mode. The only common feature among these species is the presence of two macronuclear segments, which cannot be an apomorphy as revealed by previous studies (Berger 1999; Foissner and Stoeck 2006; Paiva et al. 2009). Perhaps, more sampling and molecular information can explain these inconsistencies. The present analyses confirmed that Oxytricha spp. may be derived from different ancestors, which is consistent with the results of many previous studies (i.e. Hu et al. 2011; Shao et al. 2011, 2014). Oxytrichids with or without cortical granules are not widely separated, which may suggest this character is not a good systematic marker.

Acknowledgement. This work was supported by the National Natural Science Foundation of China (project numbers: 41576134 to XH, 31672279 to MM) and Fundamental Research Funds for the Central Universities (project number: 2017622017). Thanks are due to Prof. Weibo Song, OUC for his comments on the manuscript. We are also grateful to the editor and anonymous reviewers for their constructive suggestions.

\section{REFERENCE}

Berger H. (1999) Monograph of the Oxytrichidae (Ciliophora, Hypotrichia). Monogr. Biol. 78: 1-1080

Berger H., Foissner W. (1987) Morphology and biometry of some soil hypotrichs (Protozoa: Ciliophora). Zool. Jb. Syst. 114: 193-239

Berger H., Foissner W. (1989) Morphology and biometry of some soil hypotrichs (Protozoa, Ciliophora) from Europe and Japan. Bull. Br. Mus. Nat. Hist. (Zool.) 55: 19-46

Berger H., Foissner W. (1997) Cladistic relationships and generic characterization of oxytrichid hypotrichs (Protozoa, Ciliophora). Arch. Protistenkd. 148: 125-155

Bick H. (1972) Ciliated protozoa: an illustrated guide to the species used as biological indicators in freshwater biology. World Health Organization, Geneva

Borror A. (1972) Revision of the order Hypotrichida (Ciliophora, Protozoa). J. Protozool. 19: 11-23

Chen L., Zhao X., Shao C., Miao M., Clamp J. C. (2017a) Morphology and phylogeny of two new ciliates, Sterkiella sinica sp. nov. and Rubrioxytricha tsinlingensis sp. nov.(Protozoa, Ciliophora, Hypotrichia) from north-west China. Syst. Biodivers. 15: $131-142$

Chen X. M., Gao F., Al-Farraj S. A., Al-Rasheid K. A. S., Xu K., Song W. B. (2015) Morphology and morphogenesis of a nov- el mangrove ciliate, Sterkiella subtropica sp. nov. (Protozoa, Ciliophora, Hypotrichia), with phylogenetic analyses based on small-subunit rDNA sequence data. Int. J. Syst. Evol. Microbiol. 65: 2292-2303

Chen X. M., Lu X., Luo X., Jiang J., Shao C., Al-Rasheid K. A. S., Warren A., Song W. B. (2017b) Researches on formation of cortical patterns during morphogenesis in ciliates supported by the IRCN-BC and NSFC projects. Eur. J. Protistol. 61: 439-452

Chen X., Pan H., Huang J. B., Warren A., Al-Farraj S. A., Gao S. (2016). New considerations on the phylogeny of cyrtophorian ciliates (Protozoa, Ciliophora): expanded sampling to understand their evolutionary relationships. Zool. Scri. 45: 334-348

Chen X. M., Yan Y., Hu X., Zhu M., Ma H., Warren A. (2013) Morphology and morphogenesis of a soil ciliate, Rigidohymena candens (Kahl, 1932) Berger, 2011 (Ciliophora, Hypotricha, Oxytrichidae), with notes on its molecular phylogeny based on small-subunit rDNA sequence data. Int. J. Syst. Evol. Microbiol. 63: $1912-1921$

Corliss J. O. (1979) The Ciliated Protozoa. Characterization, Classification and Guide to the Literature. 2nd ed. Pergamon Press, New York

Dong J., Lu X., Shao C., Huang J., Al-Rasheid K. A. (2016) Morphology, morphogenesis and molecular phylogeny of a novel saline soil ciliate, Lamtostyla salina sp. nov. (Ciliophora, Hypotricha). Eur. J. Protistol. 56: 219-231

Edgar R. C. (2004) MUSCLE: multiple sequence alignment with high accuracy and high throughput. Nucleic. Acids. Res. 32: 1792-1797

Fan Y., Lu X., Huang J., Hu X., Warren A. (2016) Redescription of two little-known urostyloid ciliates, Anteholosticha randani (Grolière, 1975) Berger, 2003 and A. antecirrata Berger, 2006 (Ciliophora, Urostylida). Eur. J. Protistol. 53: 96-108

Foissner W. (1997) Soil ciliates (Protozoa: Ciliophora) from evergreen rain forests of Australia, South America and Costa Rica: diversity and description of new species. Biol. Fertil. Soils. 25: 317-339

Foissner W. (1999) Notes on the soil ciliate biota (Protozoa, Ciliophora) from the Shimba Hills in Kenya (Africa): diversity and description of three new genera and ten new species. Biodivers. Conserv. 8: 319-389

Foissner W. (2012) Schmidingerothrix extraordinaria nov. gen., nov. spec., a secondarily oligomerized hypotrich (Ciliophora, Hypotricha, Schmidingerotrichidae nov. fam.) from hypersaline soils of Africa. Eur. J. Protistol. 48: 237-251

Foissner W. (2016) Terrestrial and semiterrestrial ciliates (Protozoa, Ciliophora) from Venezuela and Galápagos. Denisia. 35: 1-912

Foissner W., Adam H. (1983) Morphologie und Morphogenese des Bodenciliaten Oxytricha granulifera sp. n. (Ciliophora, Oxytrichidae). Zool. Scr. 12: 1-11 (in German)

Foissner W., Agatha S., Berger H. (2002) Soil ciliates (Protozoa, Ciliophora) from Namibia (Southwest Africa), with emphasis on two contrasting environments, the Etosha region and the $\mathrm{Na}$ mib Desert. Part I: Text and line drawings. Part II: Photographs. Denisia. 5: 1-1459

Foissner W., Quintela-Alonso P., Al-Rasheid K. (2008) Soil ciliates from Saudi Arabia, including descriptions of two new genera and six new species. Acta Protozool. 47: 317-352

Foissner W., Stoeck T. (2006) Rigidothrix goiseri nov. gen., nov. spec.(Rigidotrichidae nov. fam.), a new "flagship" ciliate from the Niger floodplain breaks the flexibility-dogma in the classification of stichotrichine spirotrichs (Ciliophora, Spirotrichea). Eur. J. Protistol. 42: 249-267 
Gao F., Huang J., Zhao Y., Li L. F., Liu W., Miao M., Zhang Q., Li J. M., Yi Z. Z., El-Serehy H. A., Warren A., Song W. B. (2017) Systematic studies on ciliates (Alveolata, Ciliophora): progress and achievements based on molecular information. Eur. J. Protistol. 61: 409-423

Gao F., Warren A., Zhang Q., Gong J., Miao M., Sun P., Xu D., Huang J., Yi Z., Song W. B. (2016) The all-data-based evolutionary hypothesis of ciliated protists with a revised classification of the phylum Ciliophora (Eukaryota, Alveolata). Sci. Rep. 6: 24874

Hall T. A. (1999) BioEdit: a user-friendly biological sequence alignment editor and analysis program for Windows 95/98/NT. Nucleic Acids Symp. Ser. 41: 95-98

Hu X., Kusuoka Y. (2015). Two oxytrichids from the ancient Lake Biwa, Japan, with notes on morphogenesis of Notohymena australis (Ciliophora, Sporadotrichida). Acta Protozool. 54: 107-122

Hu X. Y., Hu X., Al-Rasheid K. A. S., Al-Farraj S. A., Song W. B. (2011) Insights into the phylogeny of sporadotrichid ciliates (Protozoa, Ciliophora: Hypotricha) based on genealogical analyses of multiple molecular markers. Chin. J. Oceanol. Limnol. 29: $96-102$

Huang J. B., Luo X., Bourland W. A., Gao F., Gao, S. (2016) Multigene-based phylogeny of the ciliate families Amphisiellidae and Trachelostylidae (Protozoa: Ciliophora: Hypotrichia). Mol. Phylogenet. Evol. 101: 101-110

Jiang J., Huang J., Li L., Shao C., Al-Rasheid K. A., Al-Farraj S. A., Chen Z. (2013) Morphology, ontogeny, and molecular phylogeny of two novel bakuellid-like hypotrichs (Ciliophora: Hypotrichia), with establishment of two new genera. Eur. J. Protistol. 49: 78-92

Jung J. H., Park K. M., Min G. S. (2017) Morphology and Molecular Phylogeny of Pseudocyrtohymenides lacunae nov. gen., nov. spec. (Ciliophora: Oxytrichidae) from South Korea. Acta Protozool. 1: 9-16

Kahl A. (1932) Urtiere oder Protozoa I: Wimpertiere oder Ciliata (Infusoria) 3. Spirotricha. Tierwelt Dtl. 25: 399-650

Kumar S., Bharti D., Quintela-Alonso P., Shin M. K., Terza A. L. (2016) Fine-tune investigations on three stylonychid (Ciliophora, Hypotricha) ciliates. Eur. J. Protistol. 56: 200-218

Kumar S., Foissner W. (2016) High cryptic soil ciliate (Ciliophora, Hypotrichida) diversity in Australia. Eur. J. Protistol. 53: 61-95

Kumar S., Foissner W. (2017) Morphology and ontogenesis of Stylonychia (Metastylonychia) nodulinucleata nov. subgen. (Ciliophora, Hypotricha) from Australia. Eur. J. Protistol. 57: 61-72

Kumar S., Kamra K., Bharti D., Terza A. L., Sehgal N., Warren A., Sapra G. R. (2015) Morphology, morphogenesis, and molecular phylogeny of Sterkiella tetracirrata n. sp. (Ciliophora, Oxytrichidae), from the Silent Valley National Park, India. Eur. J. Protistol. 51: 86-97

Küppers G. C., Paiva T. S., Borges B. N., Harada M. L., Garraza G. G., Mataloni, G. (2011) An Antarctic hypotrichous ciliate, Parasterkiella thompsoni (Foissner, 1996) nov. gen., nov. comb., recorded in Argentinean peat-bogs: morphology, morphogenesis, and molecular phylogeny. Eur. J. Protistol. 47: 103-123

Liu W. W., Jiang J., Xu Y., Pan X., Qu Z., Luo X., Warren A., Ma H., Pan H. (2017) Great diversity in marine ciliates: fauna studies in China seas during the years 2011-2016. Eur. J. Protistol. 61: 424-438

Luo X. T., Fan Y., Hu X., Miao M., Al-Farraj S. A., Song W. B. (2016) Morphology, ontogeny, and molecular phylogeny of two freshwater species of Deviata (Ciliophora, Hypotrichia) from southern China. J. Eukaryot. Microbiol. 63: 771-785

Luo X. T., Li L., Wang C., Bourland W., Lin X., Hu X. (2017) Morphologic and phylogenetic studies of two hypotrichous ciliates, with notes on morphogenesis in Gastrostyla steinii Engelmann, 1862 (Ciliophora, Hypotrichia). Eur. J. Protistol. 60: 119-133

Lv Z., Chen L., Chen L., Shao C., Miao M., Warren A. (2013) Morphogenesis and molecular phylogeny of a new freshwater ciliate, Notohymena apoaustralis n. sp. (Ciliophora, Oxytrichidae). J. Eukaryot. Microbiol. 60: 455-466

Méndez-Sánchez D., Mayén-Estrada R., Luo X., Hu X. (2018) A new subspecies of Oxytricha granulifera (Hypotrichia: Oxytrichidae) from Mexico, with notes on its morphogenesis and phylogenetic position. J. Eukaryot. Microbiol. 65: 357-371

Medlin L., Elwood H. J., Stickel S., Sogin M. L. (1988) The characterization of enzymatically amplified eukaryotic 16S-like rRNA-coding regions. Gene. 71: 491-499

Müller O. F. (1773) Vermium terrestrium et fluviatilium seu animalium infusoriorum, helminthicorum et testaceorum, non marinorum, succincta historia. Heineck et Faber

Nylander J. A. A. (2004) MrModeltest, version 2.2. Uppsala: Evolutionary Biology Centre, Uppsala University

Paiva T. D. S., Borges B. D. N., Harada M. L., Silva-Neto I. D. (2009) Comparative phylogenetic study of Stichotrichia (Alveolata: Ciliophora: Spirotrichea) based on 18S-rDNA sequences. Genet. Mol. Res. 8: 223-246

Pan X., Bonrland W., Song W. B. (2013) Protargol synthesis: an inhouse protocol. J. Eukaryot. Microbiol. 60: 609-614

Pan X., Fan Y., Gao F., Qiu Z., Al-Farraj S. A., Warren A., Shao C. (2016) Morphology and systematics of two freshwater urostylid ciliates, with description of a new species (Protista, Ciliophora, Hypotrichia). Eur. J. Protistol. 52: 73-84

Ronquist F., Huelsenbeck J. P. (2003) MrBayes 3: Bayesian phylogenetic inference under mixed models. Bioinformatics 19: 1572-1574

Shao C., Ding Y., Al-Rasheid K. A., Al-Farraj S. A., Warren A., Song W. B. (2013a) Establishment of a new hypotrichous genus, Heterotachysoma $\mathrm{n}$. gen. and notes on the morphogenesis of Hemigastrostyla enigmatica (Ciliophora, Hypotrichia). Eur. J. Protistol. 49: 93-105

Shao C., Lu X., Ma H. (2015) A general overview of the typical 18 frontal-ventral-transverse cirri Oxytrichidae $s$. l. genera (Ciliophora, Hypotrichia). J. Ocean Univ. China 14: 1-11

Shao C., Lv Z., Pan Y., Al-Rasheid K. A., Yi Z. (2014) Morphology and phylogenetic analysis of two oxytrichid soil ciliates from China, Oxytricha paragranulifera n. sp. and Oxytricha granulifera Foissner and Adam, 1983 (Protista, Ciliophora, Hypotrichia). Int. J. Syst. Evol. Microbiol. 64: 3016-3027

Shao C., Pan X., Jiang J., Ma H., Al-Rasheid K. A. S., Warren A., Lin X. (2013b) A redescription of the oxytrichid Tetmemena pustulata (Müller, 1786) Eigner, 1999 and notes on morphogenesis in the marine urostylid Metaurostylopsis salina Lei et al., 2005 (Ciliophora, Hypotrichia). Eur. J. Protistol. 49: 272-282

Shao C., Song W. B., Al-Rasheid K. A. S., Berger H. (2011) Redefinition and reassignment of the 18-cirri genera Hemigastrostyla, Oxytricha, Urosomoida, and Actinotricha (Ciliophora, Hypotricha), and description of one new genus and two new species. Acta Protozool. 50: 263-287

Shi X., Warren A., Song W. B. (2002) Studies on the morphology and morphogenesis of Allotricha curdsi nov. spec. (Ciliophora, Hypotrichida). Acta Protozool. 41: 397-405 
Singh J., Kamra K., Sapra G. R. (2013) Morphology, ontogenesis, and molecular phylogeny of an Indian population of Cyrtohymena (Cyrtohymenides) shii, including remarks on the subgenus. Eur. J. Protistol. 49: 283-297

Song W. B. (1990) A comparative analysis of the morphology and morphogenesis of Gonostomum strenua (Engelmann, 1862) (Ciliophora, Hypotrichida) and related species. J. Protozool. 37: $249-257$

Song W. B. (2001) Morphology and morphogenesis of the marine ciliate Ponturostyla enigmatica (Dragesco \& Dragesco-Kernéis, 1986) Jankowski, 1989 (Ciliophora, Hypotrichida, Oxytrichidae). Eur. J. Protistol. 37: 181-197

Song W. B., Shao C. (2017) Ontogenetic patterns of hypotrich ciliates, first ed. Science Press, Beijing

Song W. B., Warren A. (1999) Observations on morphogenesis in a marine ciliate Tachysoma ovata (Protozoa: Ciliophora: Hypotrichida). J. Mar. Biol. Assoc. UK 79: 35-38

Song W. B., Wilbert N. (1997a) Morphological investigations on some free living ciliates (Protozoa, Ciliophora) from China seas with description of a new hypotrichous genus, Hemigastrostyla nov. gen. Arch. Protistenkd. 148: 413-444

Song W. B., Wilbert N. (1997b) Morphological studies on some free living ciliates (Ciliophora: Heterotrichida, Hypotrichida) from marine biotopes in Qingdao, China, with descriptions of three new species: Holosticha warreni nov. spec., Tachysoma ovata nov. spec. and T. dragescoi nov. spec. Eur. J. Protistol. 33: $48-62$

Song W. B., Wilbert N. (2002) Faunistic studies on marine ciliates from the Antarctic benthic area, including descriptions of one epizoic from, 6 new species and 2 new genera (Protozoa: Ciliophora). Acta Protozool. 41: 23-61

Stamatakis A., Hoover P., Rougemont J. (2008) A rapid bootstrap algorithm for the RAxML Web servers. Syst. Biol. 57: 758-771

Stein F. (1859) Der Organismus der Infusionsthiere nach eigenen Forschungen in systematischer Reihenfolge bearbeitet. I.
Abtheilung. Allgemeiner Theil und Naturgeschichte der hypotrichen Infusionsthiere. Engelmann, Leipzig

Tamura K., Dudley J., Nei M., Kumar S. (2007) MEGA4: molecular evolutionary genetics analysis (MEGA) software version 4.0. Mol. Biol. Evol. 24: 1596-1599

Weisse T., Moser M., Scheffel U., Stadler P., Berendonk T., Weithoff G., Berger H. (2013) Systematics and species-specific response to $\mathrm{pH}$ of Oxytricha acidotolerans sp. nov. and Urosomoida sp.(Ciliophora, Hypotricha) from acid mining lakes. Eur. J. Protistol. 49: 255-271

Wang J., Lyu Z., Warren A., Wang F., Shao C. (2016) Morphology, ontogeny and molecular phylogeny of a novel saline soil ciliate, Urosomoida paragiliformis n. sp. (Ciliophora, Hypotrichia). Eur. J. Protistol. 56: 79-89

Wang J., Li L., Warren A., Shao C. (2017) Morphogenesis and molecular phylogeny of the soil ciliate Rigidohymena quadrinucleata (Dragesco and Njine, 1971) Berger, 2011 (Ciliophora, Hypotricha, Oxytrichidae). Eur. J. Protistol. 60: 1-12

Wilbert N. (1975) Eine verbesserte Technik der Protargolimpragnation fur Ciliaten. Mikrokosmos 64: 171-179 (in German)

Yan Y., Fan Y., Chen X. R., Li L. F., Warren A., Al-Farraj S. A., Song W. B. (2016) Taxonomy and phylogeny of three heterotrich ciliates (Protozoa, Ciliophora), with description of a new Blepharisma species. Zool. J. Linn. Soc. 177: 320-334

Zhao X., Gao S., Fan Y., Strueder-Kypke M., Huang J. A. (2015) Phylogenetic framework of the systematically confused $\mathrm{An}$ teholosticha-Holosticha complex (Ciliophora, Hypotrichia) based on multigene analysis. Mol. Phylogenet. Evol. 91: 238247

Received on $18^{\text {th }}$ January, 2018; revised on $19^{\text {th }}$ March, 2018; accepted on $23^{\text {rd }}$ April, 2018 